\title{
Evaluation of the Market Value of the Enterprise with Consideration of Exogenous Factors
}

\section{Iryna Boiarko}

$\mathrm{PhD}$, Associate Professor, Head of the Scientific Research Department, University of Banking, Kyiv, Ukraine

\section{Arvydas Paskevicius}

Professor, Head of Finance Department, Vilnius University, Lithuania

\begin{abstract}
The interrelation between the value characteristics of the enterprise (market value and market cost) is investigated. The economic model of formation of market value of the enterprise taking into account five basic components (the potential of the enterprise, financial capital, external factors, information about the enterprise and time) is proposed. The proposed components identify the base drivers of cost formation. These drivers are the cash flow of receipts and expenditures, the cost of capital, as well as the influence of factors of risk and uncertainty. In the context of these components, a universal complex of factors of formation and destruction of the market value of the enterprise is formed and their hierarchical classification is constructed. In this classification, the levels of significance of individual components and factors for the formation of the individual and aggregate values of the enterprise are established. The substantiation of the scientific provisions set forth in this article is based on the use of general scientific methods of analysis and synthesis, research of systems, econometric meta-modelling, and also methods of analysis of hierarchies. To choose the approach to the estimation of the value of the enterprise, as well as to construct a hierarchical system of factors of formation of the value of the enterprise, we used the Tomas Saati's metod.
\end{abstract}

Keywords: market value, market cost, factor classification, endogenous factors, exogenous factors.

JEL Classification: G10, M20.

(C) The Authors, 2017. This article is published with open access at ARMG Publishing.

\section{Introduction}

Functioning of modern enterprises on a competitive basis requires constant improvement of financial management taking into account new strategic priorities, which are put forward in connection with the transformation of economic mechanisms as a result of the impact of general historical socio-political, socioeconomic processes of civilization development (globalization, internationalization, scientific and technical progress, etc.). All these changes affect the formation of the market value of the enterprises, which is the central concept of value-oriented management (Value-Based Management, VBM) - the concept of management, which defines the directions of improvement of the system of efficiency evaluation indicators, the evolution transformation of the methodology of financial analysis and control in the enterprise.

The enterprise is a special ware, which represents an independent integral system, the value of which is determined by a set of interrelated factors of different nature (financial-economic, socio-psychological, ethical, normative, legal, political, etc.), which determines the necessity of the development and implementation of special accounting methods, analysis and control of changes in these factors, assessment of their impact on the formation of the value of the enterprise and taking into account such changes in the process of making managerial decisions.

\section{Literature review}

Among the modern approaches that form theoretically and methodologically grounded value-oriented strategic management it is necessary to point out the fundamental concepts contained in the scientific works of M. Amram (2006), I. Ansoff (1989), A. Damodaran (2005), T. Koller (2005), T. Copeland (1999), L. Martin (2006), D. Medina (2006), D. Murrin, J. Stern (2001), B. Stewart (1991), K. Walsh (2003), W. F. Sharpe (2007), J. C. Van Home, J. M. Wachowicz (2008) and others. The theoretical basis for managing the value of the company was first described in the works of A. Marshall and I. Fisher, A. Rappaport, and also became the basis of the models of F. Modigliani, M. Miller (Modigliani et al., 1963, 
1958). However, most of today's researchers and practitioner analysts are oriented on later works that can be reffered to the stage of practical development of value management concepts.

The concept of value-based management is based on maximizing the growth of market cost of enterprises and the value of business for owners (through the growth of the market cost of investment objects and the received investment income on capital invested in projects of real investment). In this case, the market cost of the enterprise is considered as the main parameter characterizing the economic potential of the entity, and the dynamics of its change - as an important indicator of the quality of management.

The general methodological differences in the interpretation of the concept of "cost" within different scientific and economic schools and the differences in the information needs of different groups of users of accounting information lead to the fact that the development of the methodology of evaluation of enterprises, as well as the instruments of accounting, analysis and control in the relevant subject area occurs in two directions:

$>$ assessment from the buyer's side, determining the value of the enterprise as the price of its purchase and sale, taking into account incurred costs, both for its creation as a holistic property complex as a whole, and for certain types of property (assets);

$>$ from the position of the owner (actual or potential), treating the value of the enterprise as a set of incomes at the present stage and capitalized future income, the size of which varies with the influence of the factor of time, cost of capital and expected return, liquidity, inflation, risks, caused by the action of the complex of various factors that arise in the internal and external business environment of such an enterprise.

In our opinion, the typical mistake in the practice of managing the value of the enterprise is the focus solely on the value of business for its owners, while the enterprise in modern terms is a complex social institution. The complex socio-economic interconnections in the modern mechanism of generating value and creating the value of the enterprise make it impossible to create the value for the owners of the enterprise without obtaining value for all other interested persons.

The analysis of approaches to the selection of the composition and classification of the cost factors of the enterprise, which are available in scientific works, indicates that the authors generally do not carry out a comprehensive systematization of such factors, but focus is usually either on the detailed study and classification of internal factors, or on the construction of the system of external ones (for example, such approaches are found in the works of D. Voronkov and L. Zapasna, A. Mnatsakanian and A. Kharin, A. Freze (Freze, 2008). There is also a group of researches that did not aim to systematize and classify the factors of the cost formation, therefore authors in their work are limited only to the formation of their possible list (O. Brezitska, H. Hlinska, O. Mendrul (Mendrul, 2002), etc.).

The task of developing the methodology of strategic accounting, analysis and control in the direction of improving the assessment of the enterprise's cost characteristics (market cost and market value) remains topical, taking into account the peculiarities of their formation under the influence of both endogenous and exogenous factors.

The purpose of this study is to improve scientific approaches to assess the market value of the enterprise, taking into account the influence of factors of the internal and external environment.

\section{Research methods}

The substantiation of the scientific provisions set forth in this article is based on the use of general scientific methods of analysis and synthesis, research of systems, econometric-meta-modeling, as well as methods of analysis of hierarchies. To choose the approach to assessing the value of the enterprise in the system of value-oriented strategic management, as well as constructing a hierarchical system of factors of formation of the value of the enterprise, we used one of the most commonly used methods of hierarchy analysis - Tomas Saati's method (Saati, 2004), which allows to consider and agree on different estimates of the priority of individual elements of the system. Processing of the quantitative parameters of the evaluation of the priority of individual components was carried out using the software package Expert Choice. 


\section{Research results}

In the modern information field on the activities of business entities, users form their own idea of the value of the cost estimates of current and future results of their activities, based solely on information that is available for processing, synthesis and analysis. Differences in its quantity and quality give rise to the existence of a plurality of indices of individual value of the enterprise. As the information asymmetry level decreases, there is a gradual leveling of the differences in individual estimates of the value of the enterprise of different users of information, resulting in the fact that averaged estimation of such value by all the stakeholders is close to the value of the market value of the enterprise.

Consequently, under such conditions it is necessary to distinguish between individual and aggregate value of the enterprise. Individual value can be defined as the cost utility estimate of current and future performance of such an enterprise, which is formed by the user of information, based on the synthesis, analysis and evaluation of available and understandable for him data on the current state and expected forecast trends of the influence of factors of formation and destruction of the enterprise value. In its turn, the aggregate value of the enterprise is the averaged estimation of individual values across a wide range of persons interested in the results of the enterprise.

Figure 1 (see in Appendix) shows the relationship in the process of generalizing individual values in the aggregate value of the enterprise, as well as the transformation of the latter in the process of evaluation for a certain date in the current period into the market value of the enterprise. The system of strategically oriented accounting should be organized in such a way as to provide sufficient and reliable information about the effect and expected changes in the influence of the factors of the internal and external business environment, so that the indicators of the individual value of the enterprise, the aggregate value of the enterprise were as close as possible to its market value. Under such conditions, the aggregate value of the enterprise can become an effective tool that allows enterprises to provide clear and understandable signals within the business environment, which demonstrate to all participants of the agency relations and the market competitive advantages and forecasts that are important for their management including investment decisions.

An important component of the development of methodological tools for accounting, analysis and control in the system of strategic management of enterprises is the clear allocation and systematization of factors of formation of cost characteristics of the enterprise (values and cost), since understanding the essence and mechanisms of their operation provides the opportunity for the purposeful management influence on the processes of cost generation and prevention of its destruction.

For identification of a unique set of factors of cost formation for each enterprise, the generalizing model proposed by A. Freze (Freze, 2008), which is based on the information approach to the definition of cost components and covers the main elements of financial reporting, is useful. According to the theory of information cost, the system of strategically oriented accounting, analysis and control should be channeled to the collection, synthesis, processing and analysis of the information that leads to the creation of cost. In his model, he examines the process of forming the cost of the enterprise as a functional dependence of the latter on variables such as assets, liabilities and information about the entity that is available to investors.

At the same time, in general, while maintaining the legitimacy of the process of maximizing the value of the enterprise, based on these variables, we believe that it is formed not only by the price of attracted capital, which is determined by the volume of the formed liabilities, but by the value of the capital of the enterprise as a whole. This indicator depends on the structure of the financing sources of the enterprise as a whole (its liabilities, taking into account both the obligations and equity capital) and, accordingly, reflects not only the price of attracted capital, but also estimates of the cost of all components of the equity capital of the enterprise - functioning equity capital taking into account economic profitability of activity, retained earnings and expected efficiency of its use in future periods. Also, in our opinion, another important component of the formation of the value of the enterprise is the external and internal business environment that affects the change in the value of the enterprise through such factors as the organization of the production process, management of relations with counterparties (suppliers, buyers, creditors), political and legal, social and political, demographic, macroeconomic, market factors, etc. 
Therefore, the model of formation of the value of the enterprise, which in our opinion is the most adequate reflection of the corresponding process in the conditions of using accounting, control, informational and analytical support in the system of strategic management of the industrial enterprise, is as follows:

$$
f\left(P, C, E,{ }^{2}, t\right) \rightarrow \max
$$

where $P$ - potential of the enterprise to generate cash flows of revenues, taking into account expenditures on their formation, maintenance and use in economic activity, determined by the actual ability and potential to generate operating and investment cash flows, determined by the system of internal factors of the business environment and is reflected in the system of indicators of property state, liquidity and solvency, business activity and profitability;

$C$ - financial capital (amounts of own, outside and borrowed financing sources of the enterprise) and nonfinancial capital (reputational), which determine the weighted average cost of capital and the required level of profitability - the factors of the formation of the discount rate and capitalization rates to bring the various elements of the cash flow to the comparable type;

$E$ - external factors of the business environment that determine the level of its current competitiveness and the perspectives of its preservation and strengthening through the use of existing competitive advantages, which are determined on the basis of comparative analysis with the indicators of competitors;

$I$ - information about the enterprise available to persons interested in its activities, on the factors that form components $\mathrm{P}$ (potential), C (capital) and $\mathrm{E}$ (business environment), which forms the deviation of the company's aggregate value and generalizes individual estimates of the shareholders from the size of its market cost - the effect of asymmetry of information; in financial assessments takes the form of transaction costs;

$t$-time reflecting the measurement of the distribution of cash receipts and expenditures in the flow of actual and expected financial results of the enterprise and determines the degree of their certainty, reliability of the received value estimates.

This model allows identifying five basic components of the formation of the value and cost of any enterprise, in the context of which a unique set of factors is formed for the creation and destruction of these cost characteristics, for the collection, compilation, systematization, analysis and presentation of information on the existing and expected effects of actions, the change trends of which are oriented towards accountingand control, informational and analytical support of the system of strategic management in the enterprise. The proposed components identify the basic drivers of cost formation - cash flows of revenue and expenditure, cost of capital, as well as the impact of the factors of risk and uncertainty. This provides opportunities for: 1) creation of a hierarchical classification of the complex of factors of forming the value of the enterprise, taking into account their belonging to a certain group of basic components, relationships and interactions between them in the process of influencing the value of the enterprise; 2) increasing the accuracy of the assessment of the value of the enterprise for various categories of persons interested in its results of the activities by establishing the levels of significance (weighting factors) for the factors which are among selected components of the formation of the enterprise value.

Among the factors of forming the value of the enterprise we can distinguish the basic (universal) composition, which is taken into account by the majority of stakeholders to reflect the value of the enterprise in their individual assessments, which is identified by the results of a comparative analysis of the system of factors presented in the study on this issue. This allows us to estimate the level of significance of the factors of the cost of the enterprise by the frequency of their use, based on the quantitative composition of the categories of stakeholders and their key interests.

Table 1 shows the results of evaluation of the significance of factors, which takes into account their belonging to a certain group of basic components of the formation of the value of the enterprise, the relationships and interactions between them in the process of influencing its creation and destruction in the context of the characteristics of information needs of different categories of persons interested in the results of the enterprise activity. Levels of significance are established by dividing $100 \%$ of the possible influence between groups of factors, components of the system of factors and factors in their composition by using the rule of Fishbern. 
Table 1. Significance of factors of cost of belonging in the context of the basic components and taking into account the information needs of stakeholders

\begin{tabular}{|c|c|c|c|c|}
\hline $\begin{array}{l}\text { Component of the } \\
\text { system of factors / } \\
\text { Aggregate level of } \\
\text { significance }\end{array}$ & Factor & $\begin{array}{l}\text { Categories of stake- } \\
\text { holders that take this } \\
\text { factor into account } \\
\text { when making deci- } \\
\text { sions } \\
\end{array}$ & $\begin{array}{l}\text { Amount of } \\
\text { interests } \\
\text { affected by } \\
\text { the factor }\end{array}$ & $\begin{array}{l}\text { Level of signifi- } \\
\text { cance of the } \\
\text { factor }\end{array}$ \\
\hline \multirow{5}{*}{$\begin{array}{l}\text { Time, risk and uncer- } \\
\text { tainty }(\mathrm{t}, \mathrm{I})(0.167)\end{array}$} & Planning horizon & OMICWS & 11 & 0.133 \\
\hline & $\begin{array}{l}\text { Flow characteristics (quantity, time of } \\
\text { receipt) }\end{array}$ & OMICWS & 11 & 0.267 \\
\hline & Probability of flows (risks) & OMICWS & 11 & 0.200 \\
\hline & $\begin{array}{l}\text { Availability and sufficiency of infor- } \\
\text { mation }\end{array}$ & OMICWBS & 12 & 0.333 \\
\hline & Time of service & B & 1 & 0.067 \\
\hline \multicolumn{4}{|c|}{ Internal } & 0.500 \\
\hline \multirow{6}{*}{ Potential (P) (0.500) } & Production potential & OMICWB & 16 & 0.238 \\
\hline & Financial potential & OMICWS & 17 & 0.286 \\
\hline & Intellectual potential & OMW & 11 & 0.095 \\
\hline & Organization of production & OMW & 11 & 0.143 \\
\hline & Organization of work & OMWS & 13 & 0.190 \\
\hline & Sales organization & B & 1 & 0.048 \\
\hline \multirow{4}{*}{ Capital (C) (0.333) } & Financial capital & OMIC & 10 & 0.250 \\
\hline & Financial leverage & OMIC & 10 & 0.250 \\
\hline & Weighted average cost of capital & OMIC & 10 & 0.250 \\
\hline & Return on equity & OMW & 10 & 0.250 \\
\hline \multirow{4}{*}{$\begin{array}{l}\text { Business environment } \\
\text { (E) }(0.167)\end{array}$} & Cash flows of the enterprise & OMW & 6 & 0.300 \\
\hline & Operational cash flows & OMIC & 8 & 0.400 \\
\hline & $\begin{array}{l}\text { Price policy (using discounts system for } \\
\text { buyers) }\end{array}$ & OMC & 5 & 0.200 \\
\hline & $\begin{array}{l}\text { Level of social responsibility and partici- } \\
\text { pation in realization of public-private } \\
\text { partnership projects }\end{array}$ & $\mathrm{S}$ & 3 & 0.100 \\
\hline \multicolumn{4}{|c|}{ External } & 0.333 \\
\hline \multirow{4}{*}{ Potential (P) (0.333) } & $\begin{array}{l}\text { Financial potential (estimation of possible } \\
\text { rates of growth) }\end{array}$ & OMICWS & 13 & 0.400 \\
\hline & Financial potential (tax management) & OMW & 6 & 0.100 \\
\hline & Investment potential & OMWS & 9 & 0.200 \\
\hline & $\begin{array}{l}\text { Marketing potential (quality and innova- } \\
\text { tion of products) }\end{array}$ & OMWBS & 10 & 0.300 \\
\hline \multirow{2}{*}{ Capital (C) (0.167) } & $\begin{array}{l}\text { Nonfinancial (reputational) capital (in- } \\
\text { cluding market capitalization) }\end{array}$ & OMICWS & 13 & 0.667 \\
\hline & $\begin{array}{l}\text { Average cost of raising capital in the } \\
\text { financial market }\end{array}$ & OMICS & 11 & 0.333 \\
\hline \multirow{4}{*}{$\begin{array}{l}\text { Business environment } \\
\text { (E) }(0.500)\end{array}$} & $\begin{array}{l}\text { Required level of profitability (average } \\
\text { return of alternative directions of invest- } \\
\text { ment of capital) }\end{array}$ & OMICWS & 13 & 0.400 \\
\hline & Market conditions & OMICBS & 12 & 0.500 \\
\hline & Degree of competition in the industry & OMICWS & 13 & 0.200 \\
\hline & $\begin{array}{l}\text { Business restrictions and macroeconomic } \\
\text { industrial policy }\end{array}$ & OMWS & 9 & 0.300 \\
\hline
\end{tabular}

Notes: $\mathrm{O}$ - owners, $\mathrm{M}$ - managers, I - investors, $\mathrm{C}$ - creditors, B - consumers of products (buyers), $\mathrm{W}$ - workers, $\mathrm{S}$ - state

The performed calculations show that internal factors have a higher level of significance, compared with external ones, in the formation of individual estimates of the value of the enterprise, and consequently the impact on the creation of its market cost $(50.0 \%$ versus $33.3 \%)$. Among the internal factors a higher level of significance $(50.0 \%)$ is characteristic of the factors forming the component of the potential of the enterprise, and the lowest $(16.7 \%)$ is the business environment, while the intermediate position (significance level $33.3 \%$ ) is a component of capital. Another situation in the distribution of the significance levels is inherent to external environmental factors: the business environment component is more important $(50.0 \%)$, the average weight is potential (33.3\%), and the low value is given to factors of capital (16.7\%).

Figure 3 provides the hierarchical system of complex of factors of formation of the value of the enterprise, built on the basis of their belonging to a certain group of basic components and significance in terms of dis- 
playing in them the information needs and interests of different categories of persons interested in the results of the enterprise. Factors that shape the impact of the separate component on the cost of the enterprise have different level of significance, which allows them to form their hierarchical system, distributing factors to the basic factors (level of significance of which is higher than the level with a uniform weight distribution) and additional factors (level of significance of which is lower than the level with a uniform weight distribution proportionally to the number of factors in the group).

This classification is useful for improving the information provision of value-oriented strategic management, since it allows focusing on providing users with complete and reliable information on the actions and changes of the basic factors. This allows us to expect a higher increase in market cost due to the formation of higher individual estimations of stakeholders for the value of the enterprise to meet their interests and needs, in comparison with additional factors.

It should be noted that in the structure of our system of factors there are both elementary (for example, planning horizon) and complex factors, which are a system of indicators (for example, financial potential, investment potential, marketing potential). Consequently, the list of factors of forming the value of the enterprise is rather broad. Therefore, in order to effectively organize the information provision of value-oriented strategic management, it is important to optimize the amount of information, evaluate the optimal number of indicators that are appropriate to record, analyze and control.

\section{Conclusions}

Modern analysis and control in the system of value-oriented strategic management provide creation of the integrated system of information support, which allows to gradually track the process of formation of individual estimates of the value of the enterprise for stakeholder groups that are interested in its activities, which reflect the whole complex of existing and potential competitive advantages of such an enterprise as an effective participant of market relations, capable to set up business processes, so as to obtain the necessary financial results and generate the sufficient level of investment attractiveness for attracting capital to finance the expansion of economic activity and socio-economic development.

Quantitative and qualitative composition of the system of indicators by which users of information try to determine the current state and the expected change in the factors of formation of individual value of the enterprise is also determined by the specificity of the assessment methodological tool, which is selected by the subject of evaluation to achieve the objectives of evaluation. That is, each subject chooses those methods that most accurately reflect the value of the enterprise in the sense that meets the needs of users of such information.

Cost characteristic of the enterprise's value depends on those information signals and expectations that were received or formed by those who are interested in the results of the enterprise. In this case, only the use of accounting data is not sufficient to fully reflect the whole system of factors that affect the process of creating and destroying the value of the enterprise. Therefore, the synergetic development of economic accounting involves the formation of a strategically oriented model of accounting, analysis and control that would ensure elimination of the influence of asymmetry of information on the formation of assessment of the value and cost of the enterprise by different categories of stakeholders.

\section{References}

1. Amram, M., Martin, L., Medina, D. (2006). A Practical Guide to Tree Methods of Enterprise Valuation. Working paper.

2. Ansoff, I. (1989). Strategicheskoye upravleniye [Strategic Management]. Trans. from English by Yevenko L.I. Moscow, Economics. 519 p.

3. Cooper, R. (1998). Measure costs right: make the right decisions / R. Cooper, R.S. Kaplan. // Harvard Business Review. pp. 96-103.

4. Copeland, T. (1999). Stoimost' kompaniy : otsenka i upravleniye [Value of companies: evaluation and management]. Trans. from English. Moscow. 576 p.

5. Damodaran, A. (2005). Damodoran on Valuation. Security Analysis for Investments and Corporate Finance. - John Wiley \& Sons, Inc., 410 p.

6. Freze, A. V. (2008). Upravleniye stoimost'yu promyshlennogo predpriyatiya [anagement of the cost of an industrial enterprise]. Author's thesis. Samara. 24 p. 
7. Koller, T. (2005). Valuation: Measuring and Managing the Value of Companies / T. Koller, M. Goedhart, D. Wessels. - John Wiley \& Sons, Inc., 730 p.

8. Koryahin, M.V. (2012). Bukhhalters'kyy oblik u systemi upravlinnya vartistyu pidpryyemstva: teoretykometodolohichni kontseptsiyi [Accounting in the system of management of the cost of the enterprise: theoretical and methodological concepts] monograph. Lviv, LKA. 389 p.

9. Mendrul, O.H. (2002). Upravlinnya vartistyu pidpryyemstv [Cost management of enterprises: monograph]. Kyiv, KNEU. 272 p.

10. Modigliani, F. (1963). Taxes and the Cost of Capital: A Correction / F. Modigliani, M. Miller. // Ibid. pp. 433-443.

11. Modigliani, F. (1958). The Cost of Capital, Corporation Finance and the Theory of Investment / F. Modigliani, M. Miller. // American Economacal Reveu. pp. 261-297.

12. Palamarchuk, V.P. (2008). Prinyatiye strategicheskikh resheniy, oriyentirovannykh na rost tsennosti kompanii [Acceptance of strategic decisions aimed at increasing the company's value [Electronic resource]. 8, pp. 56-59. Available at http://www.creativeconomy.ru/articles/5824/.

13. Russman, I. B. (1968). Optimizatsiya potokov informatsii $v$ zadachakh upravleniya [Optimization of Information Flows in Control Problems]. Investigation of Economic Information Flows. Moscow. Pub. house "Nauka". pp.99-107.

14. Saati, T. (2004). Prinyatiye resheniy. Metod analiza iyerarkhiy [Decision-making. Method for analyzing hierarchies]. Trans. from English by Vachnadze R. G. Moscow, Radio i svyaz'. 278 p.

15. Sharpe, Uil'yam F. (2007). Investitsii [Investments]. Trans. from English by Burenin A. N., Vasin A. A. Moscow, INFRA-M. 1027 p.

16. Skott, M. (2002). Faktory stoimosti: rukovodstvo dlya menedzherov po vyyavleniyu rychagov sozdaniya stoimosti [Cost factors: Guidelines for managers to identify value creation mechanisms]. Trans. from English under ed. Ivanov Yu. N. Moscow, CJSC "Olimp-Biznes". 432 p.

17. Stern, Joel M. (2001). The EVA challenge : implementing value added change in an organization / by Joel M. Stern and John S. Shiely with Irwin Ross. - New York : John Wiley\&Sons, Inc. 250 p.

18. Stewart, G. Bennet (1991). The Quest For Value: the EVA Management Guide. - New York: Harper Business.

19. Van Home, Dzheyms (2008). Osnovy finansovogo menedzhmenta [Fundamentals of financial management]. Trans. from English, $12^{\text {th }}$ ed. Moscow, “I.D. Williams". 1232 p.

20. Walsh, Ciaran (2003). Key Management Ratios / Ciaran Walsh. - London: FT: Prentice Hall. 375 p. 


\section{Appendix}
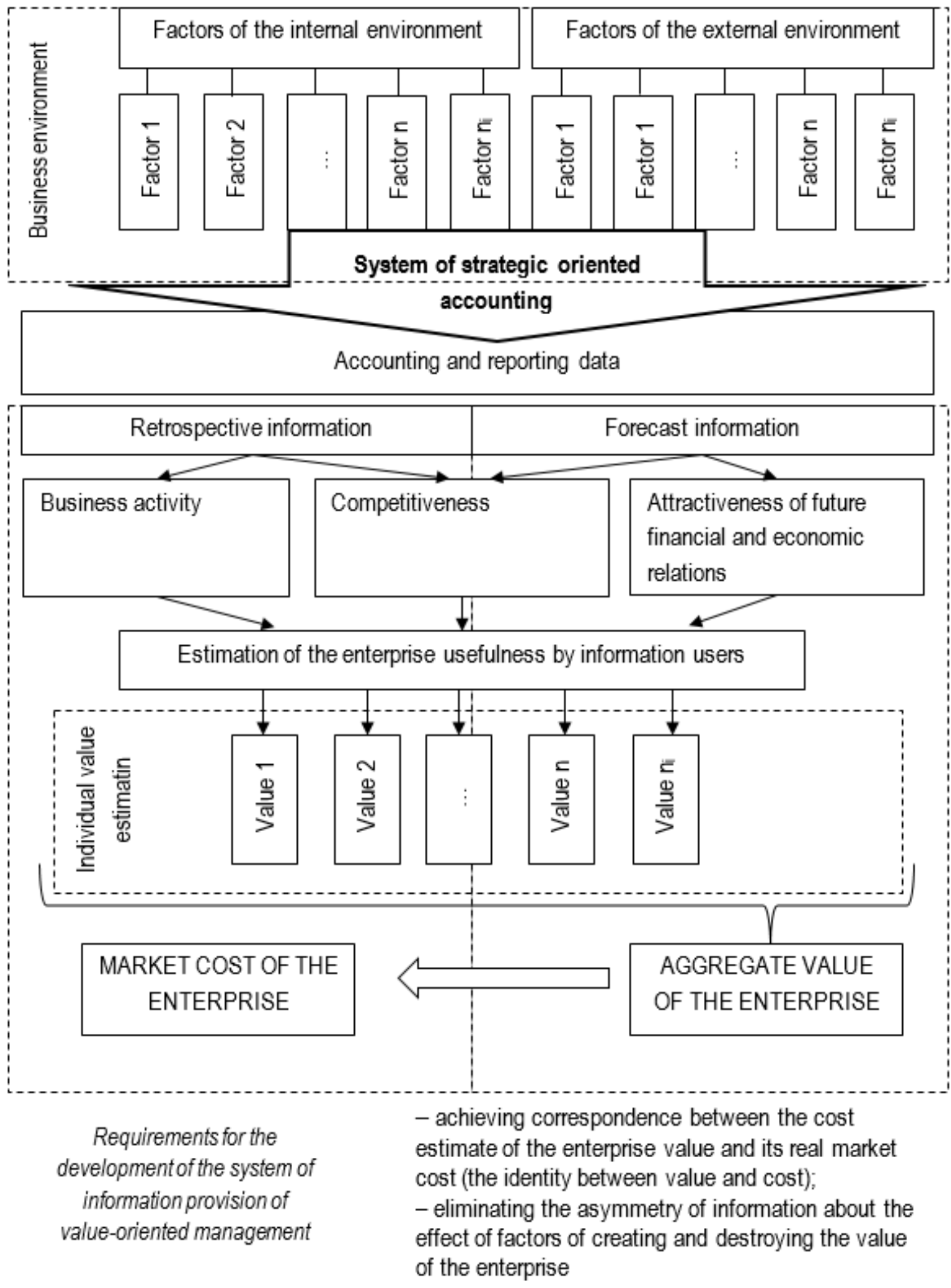

Figure 1. Formation of the market cost of the enterprise

Source: author's development. 


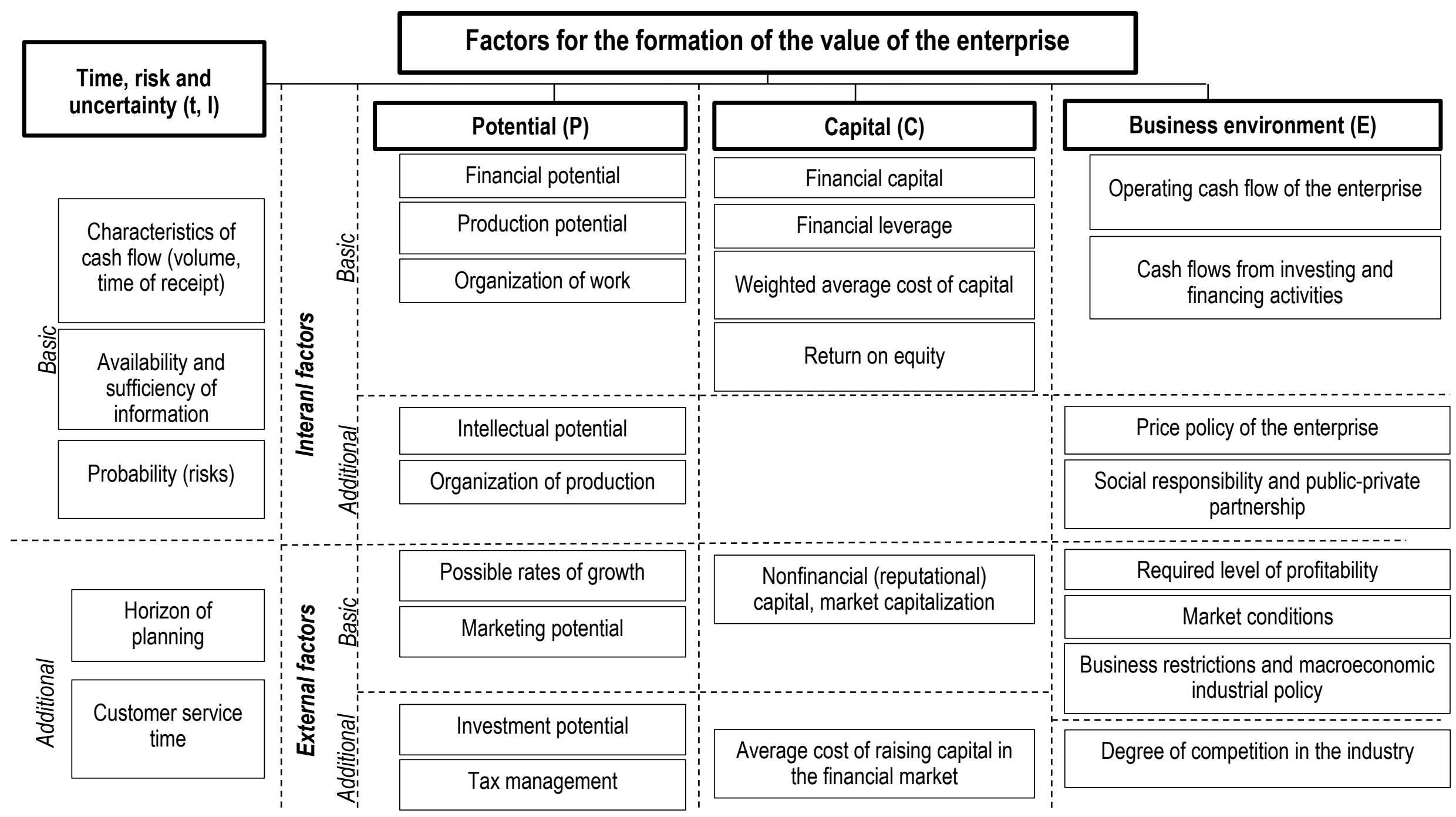

